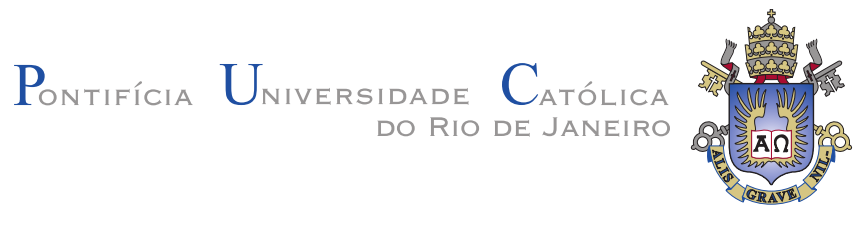

Yuri Ki

\title{
Heterodimensional cycles of co-index two and symbolic blenders
}

Tese de Doutorado

Thesis presented to the Programa de Pós-Graduação em Matemática of the Departamento de Matemática, PUC-Rio, as partial fulfillment of the requirements for the degree of Doutor em Matemática.

Advisor: Prof. Lorenzo J. Díaz 


\section{Heterodimensional cycles of co-index two and symbolic blenders}

Thesis presented to the Programa de Pós-Graduação em Matemática of the Departamento de Matemática do Centro Técnico Científico da PUC-Rio, as partial fulfillment of the requirements for the degree of Doutor.

Prof. Lorenzo J. Díaz Advisor

Departamento de Matemática - PUC-Rio

Prof. Jairo da Silva Bochi

Departamento de Matemática - PUC-Rio

Prof. Rafael Oswaldo Ruggiero Rodriguez Departamento de Matemática - PUC-Rio

Prof. Alex Lúcio Ribeiro Castro Departamento de Matemática - PUC-Rio

Prof. Isabel Lugão Rios Instituto de Matemática - UFF

Prof. Enrique Ramiro Pujals Instituto Nacional de Matemática Pura e Aplicada - IMPA

Prof. Vilton Jeovan Viana Pinheiro Instituto de Matemática - UFBA

Prof. Paul Alexander Schweitzer Departamento de Matemática - PUC-Rio

Prof. José Eugenio Leal Coordinator of the Centro Técnico Científico - PUC-Rio 
All rights reserved.

\section{Yuri Ki}

B.A. in Mathematics, Teaching Track from Universidade de São Paulo and M.A. in Mathematics, from Universidade Federal da Bahia.

Bibliographic data

Ki, Yuri

Heterodimensional cycles of co-index two and symbolic blenders / Yuri Ki; advisor: Lorenzo J. Díaz . - 2012.

$118 \mathrm{f}$. : il. ; $30 \mathrm{~cm}$

Tese (doutorado) - Pontifícia Universidade Católica do Rio de Janeiro, Departamento de Matemática, 2012.

Inclui bibliografia

1. Matemática - Teses. 2. Aplicação produto cruzado. ; 3. Atrator de Hutchinson. ; 4. Blender. ; 5. Blender simbólico. ; 6. Ciclo heterodimensional. ; 7. Ciclo robusto. ; 8. Intersecção homoclínica forte. ; 9. Hiperbolicidade parcial. ; 10. Sistemas de funções iteradas. . I. Ki, Yuri. II. Pontifícia Universidade Católica do Rio de Janeiro. Departamento de Matemática. III. Título. 


\section{Acknowledgments}

I would like to thank CNPq and PUC-Rio for the financial support.

I would like to express my sincere gratitude to my advisor Lorenzo J. Díaz for his advising, availability and patience.

To the jury members: Alex Lúcio Ribeiro Castro (PUC-Rio), Enrique Ramiro Pujals (IMPA), Isabel Lugao Rios (UFF), Jairo da Silva Bochi (PUCRio), Paul Alexander Schweitzer (PUC-Rio), Rafael Oswaldo Ruggiero Rodriguez (PUC-Rio) and Vilton Jeovan Viana Pinheiro (UFBA).

I also would like to thank to my co-workers Artem Raibekas and Pablo Barrientos.

Thanks to Christian Bonatti, Enrique Pujals, Rafael Potrie and Thiago Catalan for helpful and useful mathematical conversations.

There are a lot of people of Departamento de Matemática i would like to thank, in particular, Aninha, Creuza, Kátia, Monica, Nicolau, Renata, Sinésio. I would like to thank Flávio Abdenur for carrying the "dynamical team" during these years at PUC. I would like to thank Thomas Lewiner for helping with latex.

Thanks to all friends from PUC-Rio, in particular, Felipe, Miguel and $a$ velha-guarda for all conversations in our favorite place at the departament, the kitchen!!

Obviously, i would like to thank the caos-girls: Cris, Débora, Emília, Jaque, Lis and Paty for all jokes, laughs, laughs and more laughs!

Thanks to the amigas-band, for being present in all important moments of my life!

My deep gratitude to my parents om-ma and ap-pa, and my sister Hanna. I always have with them the support and unconditional love.

A very special acknowledgment to my family: Pablo Guarino for helping me, taking care of me and making me laugh every day and all the time! Thanks for being part of my life and making me the happiest person of the world! 


\section{Abstract}

Ki, Yuri; Díaz, Lorenzo J.. Heterodimensional cycles of coindex two and symbolic blenders. Rio de Janeiro, 2012. 118p. Tese de Doutorado - Departamento de Matemática, Pontifícia Universidade Católica do Rio de Janeiro.

In the first part of the thesis, we consider diffeomorphisms having heterodimensional cycles associated with a pair of saddles $P$ and $Q$ of co-index two. We prove that diffeomorphisms with cycles, which have at least one pair of non-real central eigenvalues, generate robust heterodimensional cycles. Moreover, when both central eigenvalues are non-real, the robust cycles are associated with the continuation of the initial saddles (i.e. the cycle can be stabilized). In the second part of this work we study skew product maps over Bernoulli shifts with contracting fibers and Hölder dependence on the base points. We prove that systems satisfying the covering property exhibit symbolic blenders. These blenders are generalizations of the usual blenders whose main property is that their central direction may have any dimension $d \geq 1$.

\section{Keywords}

Blender; Heterodimensional cycle; Hutchinson attractor; Iterated function system; Partial hyperbolicity; Robust cycle; Skew product maps; Strong homoclinic intersection; Symbolic blender. 


\section{Resumo}

Ki, Yuri; Díaz, Lorenzo J.. Ciclos heterodimensionais de coíndice dois e blenders simbólicos. Rio de Janeiro, 2012. 118p. Tese de Doutorado - Departamento de Matemática, Pontifícia Universidade Católica do Rio de Janeiro.

Na primeira parte da tese, consideramos difeomorfismos com ciclos heterodimensionais associados a um par de selas $P$ e $Q$ de co-índice dois. Provamos que difeomorfismos com ciclos que possuem no mínimo um par de autovalores centrais do ciclo não real geram ciclos heterodimensionais robustos. Além disso, quando os autovalores centrais são não-reais, os ciclos robustos estão associados as continuações das selas iniciais (ou seja, os ciclos podem ser estabilizados). Na segunda parte deste trabalho estudamos mapas produto cruzado sobre aplicações deslocamento (do tipo Bernoulli) com fibras contrativas e dependência Hölder nos pontos da base. Provamos que sistemas que satisfazem a propriedade de cobertura exibem blender simbólicos. Estes blenders são generalizações do blender usual cuja principal característica é que suas direções centrais podem ter qualquer dimensão $d \geq 1$.

\section{Palavras-chave}

Aplicação produto cruzado; Atrator de Hutchinson; Blender; Blender simbólico; Ciclo heterodimensional; Ciclo robusto; Intersecção homoclínica forte; Hiperbolicidade parcial; Sistemas de funções iteradas. 


\section{Contents}

$\begin{array}{lll}1 & \text { Introduction } & 10\end{array}$

1.1 Heterodimensional cycles of co-index two 11

Ingredients of the proof of Theorem A 14

$\begin{array}{lll}1.2 & \text { Skew product maps } & 16\end{array}$

$\begin{array}{lll}1.3 & \text { Symbolic blender-horseshoes } & 18\end{array}$

$\begin{array}{lll}1.4 & \text { One-step setting, iterated function systems, and symbolic blenders } & 19\end{array}$

1.5 Partial hyperbolicity: an application 21

1.6 Organization of this thesis 21

1.7 Colaboration 22

2 Simple cycles: the $(\mathbb{C}, \mathbb{C})$ case $\quad 23$

2.1 Partially hyperbolic dynamics 24

$2.2(\mathbb{C}, \mathbb{C})$-Simple cycles $\quad 24$

3 Strong homoclinic intersections: the $(\mathbb{C}, \mathbb{C})$ case 33

3.1 Model families 34

3.2 Bidimensional quotient families 36

3.3 Proof of Proposition 3.3 40

$3.4(\mathbb{C}, \mathbb{C})$-cycles with several quasi-transverse heteroclinic points 43

4 The $(\mathbb{R}, \mathbb{C})$ case: simple cycles, model families, and strong homoclinic intersections $\quad 49$

$4.1(\mathbb{R}, \mathbb{C})$-simple cycles $\quad 49$

4.2 Model and quotient families $\quad 54$

4.3 Strong homoclinic intersections 58

End of the proof of Proposition 4.11 59

5 Blenders $\quad 60$

5.1 Geometric model of blender $\quad 60$

Proof of Proposition $5.1 \quad 62$

5.2 Cone fields and robustness 66

Cone fields 66

Robustness $\quad 69$

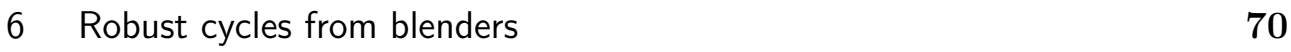

6.1 Strong homoclinic intersections yield robust cycles 70

6.2 Stabilization of $(\mathbb{C}, \mathbb{C})$-cycles $\quad 75$

7 Symbolic skew product maps $\quad 78$

$\begin{array}{lll}7.1 & \text { Invariant graph } & 78\end{array}$ 
$\begin{array}{lll}7.2 & \text { Unstable sets } & 80\end{array}$

7.3 Continuation of the reference cube 85

$8 \quad$ Symbolic blenders in the one-step setting $\quad 89$

8.1 One-step skew products and IFS's 89

8.2 Blending regions for contracting IFS: The Hutchinson attractor 92

9 Symbolic blenders in the Hölder setting $\quad 95$

9.1 Proof of Theorem C 96

10 Robust cycles from symbolic blender-horseshoes 101

10.1 Robust symbolic cycles 101

$\begin{array}{ll}10.2 \text { Heterodimensional cycles } & 109\end{array}$

$\begin{array}{ll}\text { Bibliography } & 112\end{array}$

$\begin{array}{ll}\text { A } & 115\end{array}$

$\begin{array}{ll}\text { B } & 117\end{array}$ 


\section{List of Figures}

$\begin{array}{lll}1.1 & \text { Heterodimensional cycle } & 12\end{array}$

1.2 Strong homoclinic intersection point 15

2.1 Transitions of the cycle 27

2.2 The heteroclinic points $\bar{X}_{Q}$ and $\bar{X}_{P} \quad 28$

3.1 Strong homoclinic intersection $A$ and the point $Q_{g}$

3.2 Quotient map 37

3.3 Vertical rectangle 41

$3.4 \quad H$ and $V_{m+1}$

3.5 Intersections 43

3.6 Claim $3.12 \quad 45$

3.7 Perturbation 46

3.8 The points $Y$ and $Y_{1} \quad 47$

$\begin{array}{lll}5.1 & \text { Rectangles } & 60\end{array}$

5.2 The map $F \quad 61$

$5.3 t$-vertical strips and $s$-vertical strips 62

$5.4 \phi_{1}, \phi_{2}: \mathbb{R} \rightarrow \mathbb{R}$

6.1 Points $Z, A$ and $B \quad 71$

6.2 Points $A_{1}, \ldots, A_{4}$ and $B_{1}, \ldots, B_{4} \quad 71$

$\begin{array}{lll}6.3 & \text { Sub-cubes } & 72\end{array}$

$6.4 A_{i}$ 's and $\tilde{A}_{i}$ 's $\quad 73$ 